\title{
Nature of Science Progression in School Year 1-9: a Case Study of Teachers' Suggestions and Rationales
}

\author{
Lotta Leden $^{1}$ (D) - Lena Hansson ${ }^{1}$
}

Published online: 25 July 2017

(C) The Author(s) 2017. This article is published with open access at Springerlink.com

\begin{abstract}
The inclusion of nature of science (NOS) in science education has for a long time been regarded as crucial. There is, however, a lack of research on appropriate NOS aspects for different educational levels. An even more neglected area of research is that focusing on teachers' perspectives on NOS teaching at different levels. The aim of this article is to examine NOS progression in the light of teachers' suggestions and rationales. In order to obtain teachers' informed perspectives, we chose to involve six teachers (teaching grades 1-9) in a 3 -year research project. They took part in focus group discussions about NOS and NOS teaching as well as implemented jointly planned NOS teaching sessions. Data that this article builds on was collected at the end of the project. The teachers' suggestions for NOS progression often relied on adding more NOS issues at every stage, thereby creating the foundations of a broader but not necessarily deeper understanding of NOS. Five rationales, for if/when specific NOS issues are appropriate to introduce, emerged from the analysis of the teacher discussions. Some of these rationales, including practice makes perfect and increasing levels of depth can potentially accommodate room for many NOS issues in the science classroom, while maturity and experience instead has a restricting effect on NOS teaching. Also, choice of context and teaching approaches play an important role in teachers' rationales for whether specific NOS issues should be included or not at different stages. The article discusses the implications for teacher education and professional development.
\end{abstract}

Keywords Nature of science $\cdot$ NOS progression $\cdot$ NOS teaching $\cdot$ Teachers' perspectives

\section{Introduction and Background}

For quite some time, science education researchers have argued that perspectives on nature of science (NOS) ought to be included in science teaching (Lederman 2007; Matthews 2012).

Lotta Leden

lotta.leden@hkr.se

1 LISMA, Kristianstad University, 29188 Kristianstad, Sweden 
Arguments are, for example, that NOS knowledge is an important part of scientific literacy (Driver et al. 1996; Hodson 2009), a pathway to understanding other science content (McComas et al. 1998), and a possibility to enhance students' interests in science (McComas et al. 1998; Sjøberg 2010). This has resulted in the inclusion of NOS in curricula and policy frameworks around the world (see Hodson 2014; Jenkins 2013). As a consequence, teachers must handle curricula that both explicitly and implicitly refer to NOS.

NOS teaching practices and teachers' and students' views of NOS have been investigated (Lederman 2007), as have teachers' perspectives on NOS teaching (e.g., Deniz and Adibelli 2015; Henke and Höttecke 2015; Leden et al. 2015). Despite the emphasis on NOS in research and curricula, numerous studies show that NOS is still not a natural part of science teaching. Research has thus far paid less attention to specific NOS issues that could be suitable for different educational levels (some exceptions are described below). Researching teachers' rationales for NOS teaching, and more specifically for NOS progression, could constitute one important facet in striving to understand the gap between research and practice. The present article thus takes a first step by reporting the results of a case study of six teachers' rationales and suggestions for appropriate NOS issues for different school years in Swedish compulsory school ${ }^{1}$ (school years1-9).

\section{NOS Issues for Compulsory School}

There is an ongoing controversy regarding the choice of relevant NOS aspects for school science. Suggestions have been put forth from various perspectives. One line of research has advocated lists of NOS items that could be relevant for K-12 students (Lederman 2007; McComas 1998; Osborne et al. 2003). Other suggestions have proposed more detailed descriptions like, for instance, features of science (FOS) (Matthews 2012), and the nature of whole science (Allchin 2011). Another line of research has been inspired by Ludwig Wittgenstein's family resemblance concept. With a family resemblance approach to NOS teaching, both heterogeneity and resemblances between scientific disciplines are emphasized and structured within specific categories. (e.g., Eflin et al. 1999; Erduran and Dagher 2014; Irzik and Nola 2011; van Dijk 2011). The framework of NOS themes used in the present study has its point of departure in the NOS tenets described in Lederman (2007). However, the themes have been developed with inspiration from the abovementioned debates as well as different science studies perspectives. A development means that the NOS themes become more flexible and broad, to allow for the inclusion of multiple perspectives and discussions of both general and context-specific characteristics of science (see below).

However, regardless of perspective, science education researchers agree that an important task for science education is to change or broaden students' perspectives on NOS. This is due to school science often having a narrow focus on logical and conceptual elements (Clough 2006; Duschl et al. 2006), causing students to hold a simplistic picture of scientific knowledge as absolute facts emanating from observations that automatically provide true answers about nature (Lederman 1992). In order to challenge these views, science education needs to provide students with a wide variety

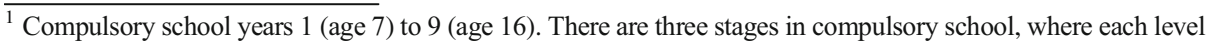
has different goals. Goals are set for year 3 , year 6 , and year 9 .
} 
of perspectives on different aspects of NOS. These perspectives should be broadened and deepened over the school years. Some suggestions for NOS issues are visible in different frameworks such as Benchmarks (AAAS 2009), A Framework for K-12 Science Education (National Research Council 2012), and Next Generation Science Standards (NGSS Lead States 2013) as well as in curricula for different countries. In some of these documents (e.g., Benchmarks (AAAS 2009)), a structure for NOS progression is clearly presented.

\section{Research on NOS Progression}

Progression Concerning Students' NOS Knowledge In some research studies (e.g., Carey and Smith 1993; Driver et al. 1996; Perry 1999; Smith and Wiser 2015), agerelated trends in students' views of NOS have been outlined. Driver et al. (1996) suggest some examples of appropriate learning activities from an epistemological perspective and from social contexts of science. Perry's (1999) developmental schemes concern stages of intellectual growth from dualism (right-wrong, good-bad) to different forms of multiplicity, moving on to contextual relativism - a scheme that outlines steps for students' meaning making of diversity of knowledge. The schemes are based on empirical studies of students in the college years, although Perry considers them to have more general implications. In his introduction to Perry (1999), Knefelkamp links different teaching approaches to Perry's developmental scheme. He argues that students in the early stages of Perry's developmental model need more guided structures and experiential learning than students in later stages. Furthermore, in science education research literature, subjective and socio-cultural aspects of science are often described as more difficult for young children to grasp than other NOS aspects (Akerson et al. 2011).

Different theories have affected the ideas of what students can learn at different stages (Bell 2006). One such theory is the biologically based Piagetian stage theory, and another is cognition theory' (Carey \& Smith 1993; Smith et al. 2000). According to stage theory, students' abilities for abstract thinking affect their understanding of NOS and younger students' supposed inability for abstract thinking hinders a deeper understanding of NOS. Cognition theory has a more flexible view of what students can learn. Bell (2006) draws the conclusion that curricula often have been guided by stage theory, which might have set unnecessary limits to the development of children's abilities to learn to reflect on abstract NOS issues. He further argues that these limits may have contributed to narrow pictures of NOS. Despite this, he still advocates modesty (waiting with the most abstract concepts until later in the educational system) and that "science educators must consider the appropriate timing of nature of science instruction" (Bell 2006 , p. 440). The present article takes on the task of considering appropriate timing by examining teachers' perspectives.

Research Suggestions Concerning a Progression for NOS Teaching In learning progression frameworks (Duschl et al. 2011), the main focus has often been on factual and conceptual knowledge, while NOS issues have only played a very modest part (Smith and Wiser 2015). In other lines of research, there are some rare examples of research on possible pathways to NOS progressions (e.g., Abd-El-Khalick 2012; Erduran and Dagher 2014). In Abd-El-Khalick (2012), a NOS progression is outlined with 
increasing levels of depth and complexity from elementary school (where certain NOS aspects are addressed as general and unproblematic) to teacher education (where the NOS aspects are emphasized as interrelated and where controversial issues should be addressed). Abd-El-Khalick defends the level of generality in elementary school by arguing that this view is still more accurate than the mythical pictures of science that are often taught. He provides examples from target NOS aspects that should be addressed at different educational levels. Below is the example of tentative NOS where progression could be described as: first, students should know that knowledge can change, second, they should know something about how it changes, and finally they should also have some knowledge of why it changes (see Table 1).

Erduran and Dagher (2014) outline a NOS progression based on a family resemblance approach (FRA). In this progression, NOS aspects (FRA categories) are linked to science teaching both horizontally (connected to science content) and vertically (connected to school year). In this way, the authors argue that students have the opportunity to encounter each aspect of NOS at every school year, connected to a variety of science topics at an increasing level of depth and complexity. Below is an example of vertical articulation for social aspects of NOS (social-institutional system) in Erduran and Dagher (2014).

In both Abd-El-Khalick (2012) and Erduran and Dagher (2014), the recommended NOS aspects to address in younger years are similar to those addressed later in the educational system, but they should "be expanded upon in greater complexity and sophistication" (Erduran and Dagher 2014, p. 170). While Abd-El-Khalick focuses on the overarching target NOS aspects, Erduran and Dagher connect specific issues to different contexts. Choosing different science contexts for the NOS issues thus becomes another way to accomplish progression by broadening students' understanding of NOS. In the above example (Table 2), an environmental context is chosen for the teaching of social aspects of science in primary school, while the context in secondary school is genetic engineering (Erduran and Dagher 2014).

Only a few studies report teachers' reflections on appropriate NOS teaching at different levels. One example is Deniz and Adibelli (2015), which shows that what the teachers consider to be developmentally appropriate concerning NOS plays an important role in their choices regarding NOS teaching. In their study, the teachers related developmental appropriateness to either teaching approach (e.g., using more complex activities with older students) or to the NOS aspect per se (e.g., difficulties in teaching theory/law relationship to young students). Leden et al. (2015) found that the teachers expected that some NOS aspects would be too abstract or too difficult for young children to grasp (e.g., social aspects of science). Another example is Henke and Höttecke (2015), who studied teachers' perspectives on obstacles during the implementation of history and philosophy of science in science (physics) teaching.

Table 1 Progression for tentative NOS as described in Abd-El-Khalick (2012, pp. 1048-1049)

\begin{tabular}{|c|c|c|}
\hline \multicolumn{2}{|l|}{ Elementary school } & Secondary school \\
\hline $\begin{array}{l}\text { Scientific } \\
\text { knowledge is } \\
\text { subject to change } \\
\text { over time }\end{array}$ & $\begin{array}{l}\text { Scientific knowledge changes in, at least, } \\
\text { two fundamental ways: (1) it is expanded } \\
\text { through accretion, and/or (2) discarded } \\
\text { and altogether replaced with new } \\
\text { knowledge. }\end{array}$ & $\begin{array}{l}\text { Scientific knowledge is expanded, revised, } \\
\text { or rejected because of two fundamental } \\
\text { reasons: (1) new evidence is brought to } \\
\text { bear [empirical NOS], and/or (2) existing } \\
\text { evidence is reinterpreted in light of theo- } \\
\text { retical advances [Theory-laden NOS] }\end{array}$ \\
\hline
\end{tabular}


Table 2 Progression for understanding science as a social-institutional system in Erduran and Dagher (2014, abridged version pp. 169-170)

\begin{tabular}{|c|c|}
\hline Primary school (environmental context) & High school (genetic engineering context) \\
\hline $\begin{array}{l}\text { Focus on scientific ethos, professional activities, and } \\
\text { social certification. }\end{array}$ & $\begin{array}{l}\text { Focus on scientific ethos, professional activities, social } \\
\text { certification, and competition among scientists. }\end{array}$ \\
\hline $\begin{array}{l}\text { How does what they [the students] did in class } \\
\text { resemble what scientists do? How do scientists } \\
\text { establish their findings? Do they change their ideas? } \\
\text { How different issues affect societal decisions (e.g., } \\
\text { biotic diversity and land use). }\end{array}$ & $\begin{array}{l}\text { How does what they [the students] did in class } \\
\text { resemble what scientists do? How do scientists get } \\
\text { better results? What societal impact does the topic } \\
\text { carry? What ethical issues confront research in this } \\
\text { area? Financial and political issues. Who owns the } \\
\text { knowledge that the scientists produce? What role do } \\
\text { legal systems and citizens play? }\end{array}$ \\
\hline
\end{tabular}

These teachers, as did the teachers in Deniz and Adibelli (2015), chose specific teaching approaches to meet students' needs in different school years. In Henke and Höttecke (2015), the teachers chose storytelling and everyday examples for teaching history of science (with references to NOS) in the early years.

The present article does not propose a theoretically developed progression for NOS through the specific learning progression framework as described in, for example, Duschl et al. (2011). Instead, we acknowledge that there could be multiple paths to progression (c.f. Johansson and Wickman 2011, 2012; Wickman and Ligozat 2011) and follow a line of research where teachers' perspectives are investigated (c.f. Deniz and Adibelli 2015; Henke and Höttecke 2015). Duschl and Wright (1989) suggest that teachers should be relieved from the task of choosing appropriate content on account of, for instance, lack of sufficient NOS understanding. However, since teachers by necessity become involved in such considerations every day, due to unspecific references to NOS in many curricula and a lack of robust teaching traditions in this area, we argue that it is of major importance to learn more about teachers' perspectives. Knowledge about teachers' perspectives can contribute with insights about the difficulties for NOS to become a substantial part of science teaching, as well as insights about how teachers' perspectives on NOS teaching at different educational levels need to be challenged and/or broadened. Such knowledge can in turn constitute important background information in the development of teacher education courses in the future, and in the long run become a tool to bridge the gap between research and practice.

\footnotetext{
Aim

As already established, research on what NOS issues are appropriate at different stages in the educational system is scarce. Even more scarce is research on teachers' perspectives on NOS progression. Therefore, the aim of this article is to shed light on in-service teachers' suggestions and rationales for what they consider to be appropriate NOS issues at different school years in Swedish compulsory school. The NOS framework that served as a point of departure for the teacher discussions is presented below. The research questions guiding this study are:

- What NOS issues do teachers suggest as appropriate at different stages in Swedish compulsory school?

- What are teachers' rationales for suggesting these issues?
} 


\section{Methods}

\section{Context}

In Sweden, science (i.e., biology, chemistry, and physics) is studied by all students throughout compulsory school. Although NOS is included in the Swedish national curriculum, and has been for the last couple of decades (Johansson \& Wickman 2012), the phrase nature of science" (in Swedish naturvetenskapernas karaktär) is not mentioned in the current curriculum (Skolverket 2011a). NOS aspects are, however, referred to both implicitly and explicitly in the curriculum and the intention to make NOS part of science teaching is strengthened by an official commentary on the curriculum (Skolverket 2011b). This is available for each subject and provided with the purpose to serve as a helpful tool for teachers when interpreting the intentions of the curriculum. In the commentary, the term nature of science is specifically mentioned:

Knowledge about the nature of science is central in order to be able to distinguish between scientific information and other ways of depicting the world. That kind of knowledge makes it possible for students to see how facts are connected to values, and to examine the interests and values behind certain positions. (Skolverket 2011b authors' translation, p. 31)

\section{Participants}

In order to investigate teachers' perspectives in-depth, we chose to involve six teachers in a project that spanned 3 years. ${ }^{2}$ The teachers were asked to participate in the project after having responded to the VNOS-C questionnaire (Lederman et al. 2002) and completed an extended follow-up interview about NOS and NOS teaching (see Leden et al. 2015). The participants were chosen with the intent that the group would comprise experiences that spanned the entire compulsory school (school years 1-9, ages 7-16). All participants were qualified for science teaching for the school years indicated in Table 3. The teachers taught at four different schools and all of them had significant teaching experience, i.e., over 10 years (see Table 3 for details). During the project, the teachers gained experience of NOS and NOS teaching from readings, discussions, and implementation of NOS activities, which enabled us to gain their informed perspectives at the end of the project. For more details about their experiences and the design of the project, see below and Leden et al. (2015).

\section{Research Project and Data Collection}

Teachers' NOS Experience Based on Their Involvement in the Research Project The research project spanned 3 years and included 12 focus-group meetings, 2 hours (h) at a time (see Fig. 1 for an outline of the project and focus group activities). A fruitful way to trigger discussions among the participants is for them to have access to material with which to work in

\footnotetext{
${ }^{2}$ There is one exception to this. Emma has replaced another participant and has only participated in the last year of the project. 
Table 3 Pseudonyms and particulars for teachers participating in the project

\begin{tabular}{lll}
\hline & Years in teaching & Teacher education aimed at school years \\
\hline Agnes & 18 & $1-7$ \\
Carolyn & 34 & $4-6$ \\
Ella & 19 & $1-7$ \\
Emma & 14 & $4-9$ \\
John & 17 & $4-9$ \\
Nina & 12 & $4-9$ \\
\hline
\end{tabular}

the focus group (Wibeck 2010). Thus, in connection with the focus group meetings the participants were often provided with working material from the moderator of the discussions. This material consisted of short texts to read before the meetings or tasks to work with during the meetings. The texts and discussions were based on a framework consisting of seven NOS themes (the seven themes were later reduced to five themes based on the teacher discussions). The NOS themes were comprehensive and broad in order to allow for multiple perspectives and a large variety of NOS issues to be included as suggested in, for example, Allchin (2011) and Erduran and Dagher (2014). They have a starting point in the NOS tenets described by Lederman (2007), but were further developed and inspired by science studies perspectives as suggested in Duschl et al. (2006). The themes are briefly described below (for a more in depth description see Leden et al. 2015):

- Tentative aspects of science was concerned with continuity/change and certainty/ uncertainty in relation to scientific knowledge. Both historical and contemporary examples coupled to different disciplines are of importance.

- Empirical aspects of science was, in addition to the significance of empirical contributions to science, broadened to include theoretical contributions and their interconnection with empirical contributions, and aspects concerned with scientific practices (c.f. Erduran and Dagher 2014). Relevant topics are, for example, the roles and relations between observations, experiments, models, and laws; trustworthiness; diversity of methods; and boundaries of science.

- Subjective aspects of science was concerned with subjectivity and objectivity in relation to scientific knowledge and at different stages of the research process. Relevant topics are, for example, theory-laden/neutral observations and background factors.

- Creative aspects of science was concerned with creativity and rationality in relation to the research process (from problem stating to interpreting observations and inventing explanations).

- Socio-cultural aspects of science was concerned with the extent to which science is influenced by society/culture, and the extent to which science is universal. Both historical and contemporary contexts are important to this theme as well as a number of perspectives such as: economy, politics, and social practices of different scientific disciplines.

During the second and third years, the teachers planned NOS activities that were later implemented in their own classrooms and thereafter reflected on in the following focus group meetings (see Fig. 1). One of the activities was highly contextualized and focused mainly on subjective and socio-cultural aspects of science through reading and discussing web-based information and news articles about a socio-scientific issue. The 


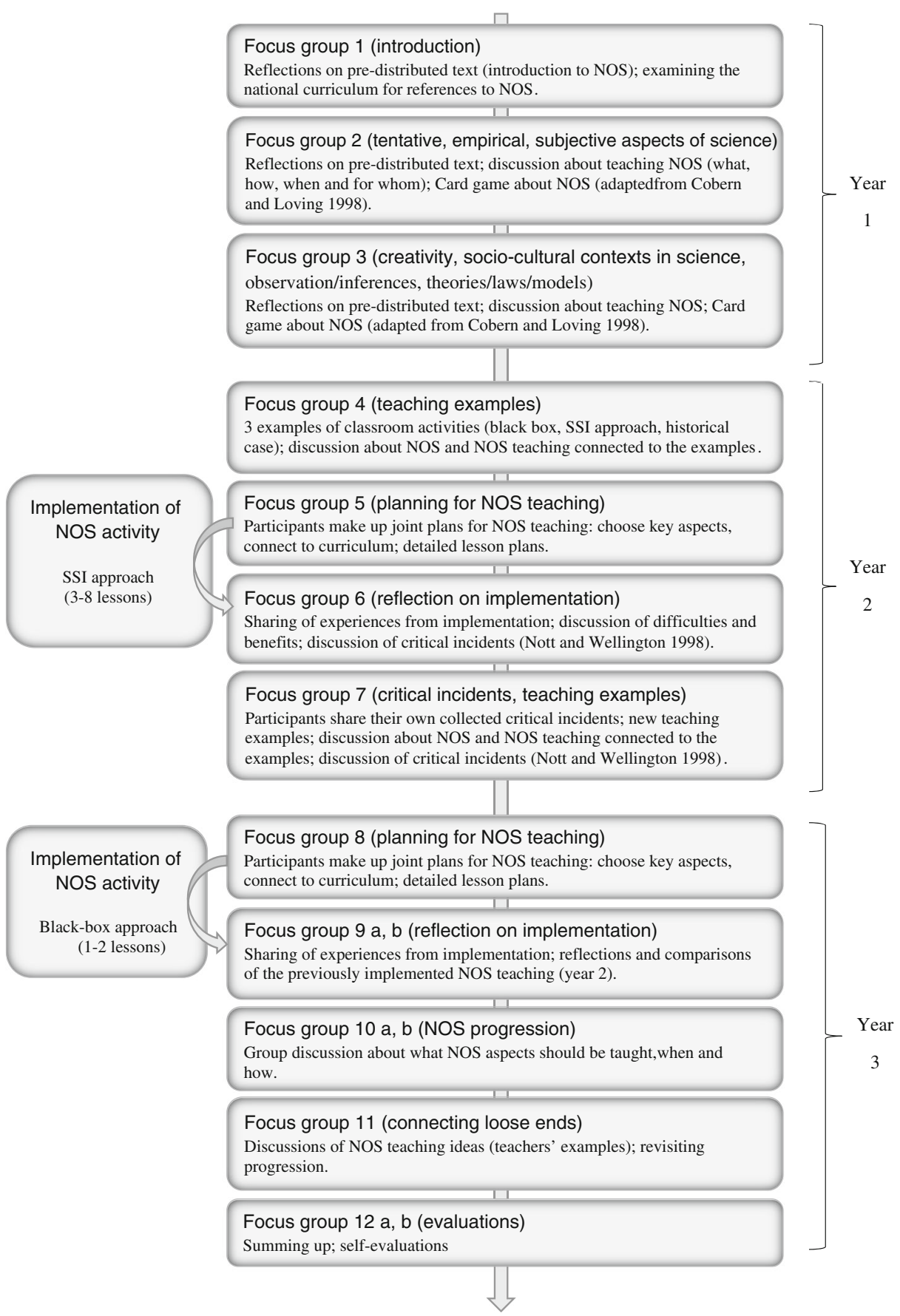

Fig. 1 Outline of the research project

other activity was a black-box activity where the students encountered all of the above described aspects of science. Thus, at the end of the project, even if the teachers were not 
experts on NOS, they had gained a higher level of experience in NOS and NOS teaching than could be expected from most teachers in Sweden.

Data This article builds on data from the recorded discussions from three focus group meetings (10a, $10 \mathrm{~b}$, and 11; see Fig. 1) at the end of the project when the teachers had experience from both NOS discussions and NOS teaching. During the first two meetings, the teachers were brought together to suggest appropriate NOS issues for years 13, 4-6, and 7-9. The NOS theme framework (see above) served as a basis for the discussions. These two focus group meetings dealt with the same things, but due to practical reasons not all teachers had the chance to participate at the same meeting. During the third meeting, four of the participants had the opportunity to elaborate on and make changes to a summary of their former discussions (summarized in a table by the first author). The teachers clarified their meanings and provided further examples, but no major changes were suggested. The first author of this article was also the moderator of all focus group meetings. The meetings were audio recorded and fully transcribed.

\section{Analysis}

The first part of the analysis focused on the suggestions put forward by the group regarding different NOS issues for each educational level. It followed the phases of thematic coding analysis described in Robson (2011) and was based on repeated reading and coding of the focus group transcripts. The suggestions were coded using the themes described above as a lens. The coding was started in the focus groups by the participants themselves since the themes were used as a trigger for the discussions. However, during the continued analysis there was a need for re-coding, structuring, and interpretation due to the teachers', sometimes, unstructured debate. The teachers jointly made a few notes in a table, but most of their suggestions were verbal as they moved back and forth between topics. The interactions and negotiations among the participants provide data on consensus and diversity. This makes focus groups suitable for learning about taken-forgranted patterns, meaning making, and tensions within a certain group (Halkier 2010). In this study, diverging suggestions were, at times, put forward during the meetings. This article presents all suggestions that were up for thorough discussion (see Table 4). Diverging suggestions and discussions demonstrate that there are interesting tensions between different rationales. The analysis of focus group data needs to seek a balance that acknowledges the interaction between the individual and the group (Morgan 1997). The analysis in this article is directed towards the discussions taking place in the group and not on statements made by single teachers. Thus, quotations in the "Results" section are presented as part of a joint, ongoing discussion and individuals only become visible (represented by numbers) when clarification is required in a dialogue.

The second part of the analysis focused on the teachers' rationales for their suggestions. In this part of the analysis there were no pre-developed categories, but instead an empirically grounded analysis was performed (Glaser and Strauss 1967). The transcripts were searched for patterns in the teachers' rationales. A provisional categorization was made, followed by a repeated restructuring as a result of comparisons of the categories to each other and to the data. This finally resulted in the five rationales described below. NVivo was used as a tool in both parts of the analysis. 


\section{Results}

In this section, we present the results of the analysis of the teachers' suggestions and rationales with respect to NOS progression in compulsory school.

\section{Teachers' Suggestions of NOS Issues}

A summary of the teachers' suggestions regarding appropriate NOS issues at different school levels can be found in Table 4. The teachers never suggested that the students should learn to memorize certain facts about NOS. Instead, they always discussed NOS as a useful tool when dealing with, for example, socio-scientific issues, argumentation, and critical thinking.

Overall, there were two different kinds of progression represented in the teachers' suggestions. In the most commonly described progression, the number of issues within each theme gradually increased over the years. This kind of progression was suggested for empirical and socio-cultural aspects of science (see themes 2 and 5, Table 4). It mainly generates possibilities for a broader understanding of NOS. In the other kind of progression, the same issue was discussed in more complex ways through, for example, adding perspectives and by elaborating on how and why science is changing. Such a progression generates possibilities for a deeper understanding of specific NOS issues. This kind of progression is more rarely described by the teachers and never suggested for an entire theme, but is used only for a few specific issues: science as changing and the role of background factors (themes 1 and 3, Table 4).

For the first kind of progression, based on adding issues, the greatest differences in the teachers' choice of NOS issues could be found between years 1-3 and 4-6 (see Table 4). For years 1-3 fewer issues were chosen. This was, for example, the case for socio-cultural aspects (theme 5, Table 4) where different world views was the only issue chosen for years 1-3, while a great variety of issues, such as economy and values, were suggested for years 4-9. However, for years 4-6 and 7-9, only a few issues differed and sometimes there were no differences at all, as was the case for subjective and creative aspects (themes 3 and 4, Table 4). Important to note, however, is that the teachers actually do suggest issues from all of the above NOS themes to be taught at all stages.

The theme demonstrating the most obvious examples of the latter kind of progression was tentative aspects of science (theme 1, Table 4). For this theme, more complex perspectives were suggested over the years. One example is that for years 1-3 the students should, according to the teachers, know that scientific knowledge has developed during history, while students in years 7-9 should know that there are current topics that lack answers and where uncertainty prevails (e.g., diverging theories in frontline science). This means that students at different stages could be presented with different images of science; younger students will be presented with the image of a science in progress, while students at later stages will be provided with additional images of science as uncertain (Table 4).

\section{Teachers' Rationales}

To better understand why teachers suggest certain NOS issues for specific school years, the transcripts were examined for their motives. This part of the analysis resulted in the identification of five rationales:

1. Maturity and experience.

2. Increasing levels of depth. 


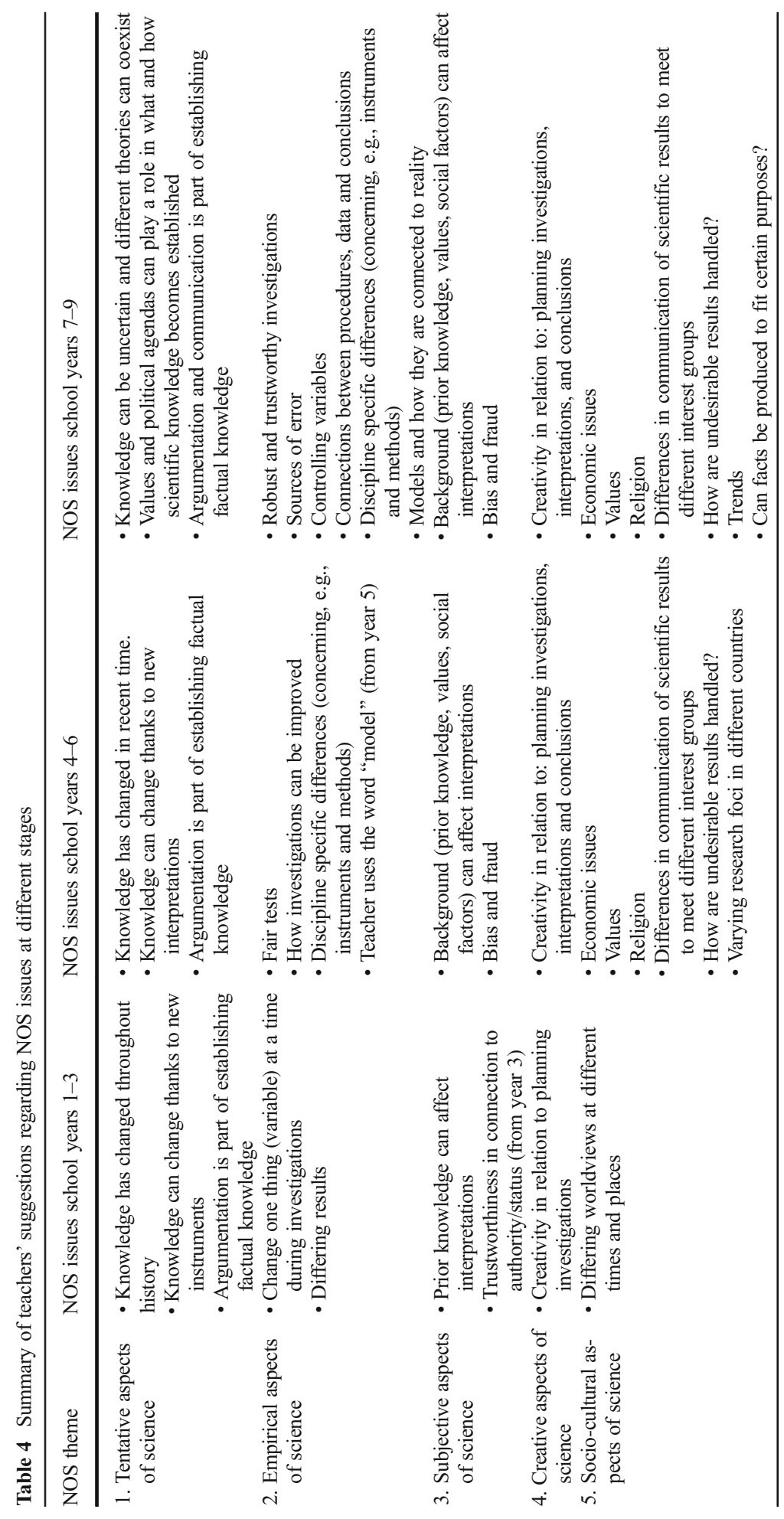


3. Practice makes perfect.

4. Choice of context.

5. Teaching approaches.

The different rationales are intertwined and not exclusive. Each rationale is described below and illustrated with excerpts from the focus group discussions.

Maturity and Experience The teachers talked about their students in terms of having inherent attributes/abilities linked to their age or maturity. One such ability, often referred to by the teachers, was the ability for abstract thinking:

Because it's so amazingly abstract when you can't touch it or see it properly. So that to understand that models are just models, they [the students] probably actually need to be rather old because that abstractness is hard.

Due to the students' maturity, certain NOS issues and ways of talking about science were chosen as appropriate for different school years. Some NOS themes, specifically subjective and socio-cultural aspects of science (themes 3 and 5, Table 4), were considered particularly abstract. For that reason, the teachers often argued that they should be avoided in the earlier years (c.f. Akerson et al. 2011; Leden et al. 2015). Despite this, the teachers suggested some issues from these themes that could be comprehensible to younger children. One example is differing worldviews (theme 5) that could be made comprehensible (less abstract) through narratives or historical anecdotes (see also teaching approaches). This suggestion is also in line with demands in the national curriculum that teaching should deal with: "Narratives about science from earlier times, and the attempts of different cultures to understand and explain phenomena in nature" (Skolverket 2011a, p. 127). Meanwhile, other NOS themes, specifically empirical and creative aspects of science (themes 2 and 4), were talked about as just the opposite. They were suggested as appropriate for early years since they were regarded as concrete and could often be dealt with in combination with hands-on tasks (see concrete approaches in choice of context). Creativity in science (theme 4, Table 4) was even considered easier to teach to young students since they were talked about as being more creative and less worried about right and wrong. The teachers argued that young students have a fundamentally different way of handling creativity: "The younger they are the more imagination they have". 3

Another way in which the teachers made suggestions related to age was their expectations of students' experiences: if the students are too young to have experienced certain everyday issues or scientific issues then they will not be able to understand the NOS issues that are connected to them. One example of this was that NOS issues related to political decisions (theme 5) were considered most suitable for the later stages of compulsory school, as younger students were not expected to have enough experience of political matters. Another example was NOS issues (e.g., scientific knowledge as uncertain, in theme 1) that, according to the teachers, were best addressed in connection to frontline science. In these cases, young students

\footnotetext{
${ }^{3}$ This is, however, connected to the teachers' suggestions that, for young students, creativity in science is supposed to be taught through students' own experiences of creativity during, for example, the planning of investigations, and not connected to scientific research practices (see also Authors 2015). For the later stages, there were other suggestions connected to creativity (see Table 4).
} 
were expected to have no/limited experience, and therefore this NOS issue ought to be dealt with in later school years.

Although arguing from the point of maturity and experience was common when the teachers justified their suggestions, it should be noted that the teachers emphasized that students in a certain school year could be at different levels of maturity. The association between age and ability for abstract thinking was also questioned: “...I think you should have high expectations on younger children /.../I think that people generally underestimate younger children". Another example of questioning the relationship between age and ability is the following quotation where lack of creativity among older students is explained by school culture (through, for example, certain assessment traditions) rather than maturity. "Here [in years 7-9] it's somehow like, in some implicit way, I don't dare to be wrong because then I flunk".

Increasing Levels of Depth Another common way of talking about NOS progression was through arguing that the teaching of a specific NOS issue could be dealt with at different levels of depth depending on school year. This meant that many issues within each theme, according to the teachers, could be addressed at any stage if addressed at the appropriate level of depth. In the following quotation, the teachers talked about how to teach scientific knowledge as changing:

Teacher 1: ...it's like that all the time. They [the scientists] learn more and more.

Teacher 2: Yes, but I believe that students can have difficulties seeing precisely that. They more or less declare early scientists as stupid: "How could they believe that?"

Teacher 1: Well yes, but I believe that it is important that you can look at: this is what people believed before, now they believe this, what will they believe in the future...

Teacher 2: Well, I think you could take that discussion through all [school] stages and then as you say [referring to an issue discussed earlier] it gets deeper and deeper/.../

Moderator: Explain once more what you mean by deeper and deeper.

Teacher 2: That they can analyse and reflect in a deeper way, due to more knowledge and greater competence...

In the rationale, increasing levels of depth NOS progression became more explicit than in other rationales, in that the suggested issues should be treated at a greater level of complexity/ depth at later stages. Most of the time, however, the teachers were not very precise in respect to what "deeper and deeper" meant for each specific issue. Yet, by studying the suggestions for tentative aspects of science (theme 1, Table 4), which was the theme discussed above, we can see that, in this case, the increasing level of depth could be related to a greater amount of reasons for scientific knowledge to change in relation to a variety of contexts.

Practice Makes Perfect Unlike arguing from the point of maturity and experience (where different issues are suggested for different stages) or increasing levels of depth, arguing from the point of practice makes perfect means the exact opposite: the same thing should be taught irrespective of stage. Even if some NOS issues, and sometimes entire NOS themes, were talked about as hard for the young students to grasp (see maturity and experience), the teachers still suggested that such issues should be taught at early stages. The teachers argued that by confronting students with abstract issues at early stages, they would be able to better understand these issues at later stages. One example of this is the following dialogue about using 
articles as a basis for discussions about differing interpretations among researchers (theme 3 , Table 4):

Teacher 1: Still you have to be trained. You have to be trained to get in to it.

Teacher 2: Yes, you could probably start early so that you somehow get used to it...

Teacher 1: But, it's not for certain that you could be particularly good.

Teacher 2: I don't really feel that you could wait until school year nine, but still, it feels like they would have the best preconditions to manage it. But then you have to have encountered it before in some way.

Teacher 1: Then you have to have started before.

Thus, in a way, through such a rationale, the teachers did not argue for a NOS progression in terms of the choice of issues - no differentiation was made. Instead, according to the teachers, the same issues ought to be repeatedly addressed so that the students in the end would have acquired more knowledge about them. Consequently, through this rationale, a progression for students' learning about NOS is discussed, even if no progression is suggested for the actual teaching.

Choice of Context The teachers frequently argued from the point of choice of context. Here, context should be understood in a broad way: sometimes it relates to the teachers' discussions about scientific context and sometimes it relates to specific examples or authentic cases. Through this rationale, the teachers did not suggest a progression for a specific NOS issue; instead, the same issue was suggested for all levels but connected to different contexts: "...you could in fact bring that up at any stage if only you have a good example...". Suggestions and examples of differing contexts were, however, often lacking in the teachers' suggestions, which is something that the teachers themselves identified as a problem- the "good example(s)" were absent.

The teachers connected the choice of contexts to notions of abstract and concrete (see also maturity and experience). They argued that concrete contexts were suitable for less experienced (young) students and connected to the students' own experiences, everyday examples, and "simple" science. Abstract contexts were associated with more experienced (older) students and connected to contemporary cases, advanced science, and science in the making.

...well, the older they get the more unfamiliar it should preferably be able to be, but of course it must be easier with a well-known situation also in school year nine...

Consequently, teachers chose concrete contexts for the early stages and more abstract ones for the later stages. However, as in the example above, the teachers could also choose concrete contexts for the older students in order to facilitate the addressing of an abstract issue.

A typical example of arguing from the point of choice of context concerns tentative aspects of science (theme 1, Table 4). For this theme, the teachers suggested different contexts for learning about scientific knowledge as open to change. For the early stages, the universe closest to Earth (the moon) was chosen as a context: "the moon — even the smallest kid knows what that is". For the later stages, the solar system and then the entire universe were chosenfurther away from the student in both space and time, as well as connected to more complex science. The teachers argued that concrete contexts offer possibilities to start early with difficult topics such as being involved in critical thinking connected to, for example, subjective 
aspects of science (theme 3, Table 4): "You can do it at primary school [school years 1-3] if it is [a] concrete enough [topic]".

Connecting a certain issue to different contexts could be a starting point for NOS progression. The teachers argued that there is a possibility that more complex science concepts/areas could lead to more complex NOS issues.

I think these things go hand-in-hand because when the content becomes more abstract then it becomes more abstract in subjectivity—well, in explaining subjectivity [about subjectivity in science theme 3, Table 4].

Teaching Approaches The teachers talked a great deal about the importance of choosing appropriate teaching approaches for NOS teaching at each educational level. Different teaching approaches were, in the teachers' discussions, connected both to stage and specific NOS issues. This connection played a role for when a certain NOS issue could be introduced. Consequently, if an issue could be taught through a concrete or hands-on-approach then it was suggested for the early school years, otherwise it would have to wait. One example is that teachers connected hands-on approaches to creative or empirical aspects of science (themes 2 and 4), which, according to them, make these aspects easy to start with at early stages. On the other hand, issues connected to socio-cultural aspects of science (theme 5, Table 4) were considered difficult to approach in a concrete way, and thus made them more appropriate for later stages.

However, in many ways, teaching approaches also resemble choice of context in that it became a way of discussing NOS progression without actually suggesting a differentiation concerning the NOS issues for different educational stages. That is, the same NOS issue was often suggested for all levels but with different teaching approaches. This could be understood as either a way to avoid suggesting a NOS progression, or as an implicit way of suggesting it.

Firstly, emphasizing teaching approaches could be a way to avoid having to make difficult decisions on a differentiated NOS.

...Well, I think that the level of the knowledge is probably not excessively higher /.../

Instead it's more like you repeat it and maybe tell it in another way /.../ Perhaps you go through it more theoretically. ${ }^{4}$

Suggesting the same NOS issues but changing approaches could, however, create opportunities for an early start with difficult issues. One example is group work, which was often suggested for the early stages as the students would then be able to scaffold each other in discussions about abstract NOS issues. ${ }^{5}$

Secondly, suggesting different approaches could actually mean progression for NOS as well, although this is not clearly pronounced. Thus, even if the same NOS issue is suggested for all stages, the changed approach could mean that a deeper or more complex understanding is achieved. This is exemplified when teachers argue that the students will gain different levels

\footnotetext{
${ }^{4}$ Here, theoretical is suggested as opposed to a practical approach (e.g., in the context of discussing molecule models, the teacher writes or draws pictures on the table, as opposed to role play among students).

${ }^{5}$ This is something that the teachers in this study have experienced from trying activities in their classes connected to socio-cultural aspects (theme 5, Table 4).
} 
of understanding if an issue is mentioned in a discussion led by the teacher, or if the students are urged to write their own article about it.

\section{Discussion}

Despite a long-lasting emphasis on NOS in science education research, NOS is seldom a selfevident part of science teaching. This article is an attempt to examine the gap between research and practice with a starting point in teachers' perspectives. From previous research (e.g., Deniz and Adibelli 2015), we know that teachers' considerations about developmentally appropriate NOS are important for their choices with regards to NOS teaching. However, although much research has been carried out on NOS teaching, there are only a few contributions to the field when it comes to NOS teaching at different levels in the educational system (among these are Abd-El-Khalick 2012; Erduran and Dagher 2014). The present article adds to previous research with deeper knowledge about teachers' perspectives on these matters. The teachers in this study have experience from many years of science teaching. Furthermore, as participants in a longitudinal research project (see above), they have regularly discussed NOS and NOS teaching, as well as developed, implemented, and evaluated NOS lessons in their science classes. With these experiences as a background, we asked them to talk about relevant NOS issues for different school years, and how a progression with respect to different NOS themes could be built into the compulsory school syllabus. Knowledge about teachers' rationales can help us understand factors that are taken into consideration by teachers and are important to them in their everyday practice. Thus, the results presented in this article constitute a valuable complement to the suggestions and theoretical discussions about NOS progressions in the science education literature. This knowledge can also serve as a basis when trying to meet preservice and in-service teachers' needs in teacher education and in professional development courses. This is a first step towards trying to understand teachers' choices and rationales with regard to NOS teaching at different levels in the educational system. More studies in different contexts are certainly needed. Below the results are discussed in relation to previous research on NOS teaching.

\section{Teachers' Suggestions}

In science education literature, there are some examples of research-based suggestions for NOS progressions. As seen above, these suggestions include a broader span of NOS issues and different contexts at later stages (e.g., Erduran and Dagher 2014), and/or a deeper treatment of specific NOS issues (e.g., Abd-El-Khalick 2012). However, the paths to progression through broadening or deepening are intertwined and hard to separate from one another. To offer different perspectives on an issue could mean broadening through gaining understanding about more detailed issues, and deepening through creating possibilities for an increased level of complexity on the same issue.

Another issue discussed in the literature is at what stage NOS teaching could start and what kind of NOS issues could be introduced for young students (e.g., in elementary school). AbdEl-Khalick (2012), for example, provides rather general and un-complex suggestions for the early years. Other studies (e.g., Akerson et al. 2011) discuss socio-cultural aspects of science as particularly difficult to introduce to the youngest students. In contrast, the teachers in this study 
sometimes suggest what they themselves describe as abstract and complex issues at earlier stages, since they argue that there are gains to be made by starting early (see also below). This is in line with the progression outlined by Erduran and Dagher (2014), who present a large variety of topics at early stages.

The results presented in this article show that the progressions suggested by the teachers primarily means adding more issues for later stages, than deepening the perspective of already introduced NOS issues. This builds a certain kind of NOS progression that broadens the students' understanding of NOS. Thus, it is not certain that the kind of progression that is visible in the overview of these teachers' suggestions will constitute a basis for a considerably deeper understanding of a specific NOS issue. In contrast, Abd-El-Khalick (2012) outlines a progression for a certain target NOS aspect. In the example of tentative NOS (see above), progress is stretching from scientific knowledge is changing to how and why this happens. The results discussed in this article show that such elaborations on how and why are less common, although not missing, in teachers' suggestions. However, it is important to note that teachers' suggestions must be interpreted in light of their rationales, as some rationales open up for a more complex understanding of the chosen NOS issues.

\section{Teachers' Rationales}

We have presented five different rationales that seem to guide the suggestions put forth by the teachers. Some of these rationales provide an obvious potential for the inclusion of NOS in classroom practice, while others will be more likely to hamper the inclusion of NOS.

Arguing from the point of practice makes perfect and increasing levels of depth could have a positive influence on NOS teaching - everything becomes possible. Through these rationales, a number of issues can be brought to the fore even at early stages - issues that could be returned to over the years either as some sort of repetition or at greater levels of depth. In contrast, there is a risk that arguing from the point of maturity and experience could have a negative influence on the introduction of NOS issues. However, this rationale is the most explicit way of outlining a progression for NOS - some issues are suggested for early stages and some issues for laterfocusing on what is considered abstract and concrete for children at different educational levels. Following such a rationale, certain NOS issues are excluded from science teaching in the early years since they are considered to be too abstract. This is in line with stage theory and could perhaps lead to unnecessary restrictions/constraints to NOS teaching in general (Bell 2006) and to NOS teaching for younger students and certain NOS themes. We know from previous studies (e.g., Akerson et al. 2011) that subjective and socio-cultural aspects of science are often considered more appropriate for later stages in the school system. There could, however, be some reason to problematize this notion. One example of how multiple issues from the "social-institutional system" (as well as the other FRA categories) are proposed already in primary schools is Erduran and Dagher (2014). For NOS to become a part of science teaching in the early years, teachers will need examples where they can see this happening. Such "success-examples" could constitute one way to challenge perceived difficulties regarding maturity and experience. Thus, there is a need for more research about NOS teaching and young students (one example of research on NOS in the early years is Akerson and Donnelly 2010). There is also an urgent need for good examples of how NOS can be taught in a meaningful way in years $1-3$.

Arguing from the point of teaching approaches or choice of context can cause constraints as well as possibilities for NOS teaching. Opportunities arise when teachers find certain ways to approach issues that are considered abstract. One of their suggestions, in line with Knefelkamp in Perry 
(1999), is more hands-on approaches for younger students. Constraints appear when teachers do not have access to adequate contexts/examples or approaches. It is also important to note that arguments from the point of choice of contexts or teaching approaches could mean two things for progression. It could mean that there is no specific NOS progression at all, since the same issues are suggested for all stages. The only thing that differs between the educational stages is that the NOS issue in focus is connected to different examples or addressed through different approaches. On the other hand, arguing from the starting point in choice of contexts or teaching approaches could contribute to a progression thanks to the broader span of NOS issues that might be brought to the fore in connection with different or more complex contexts. More complex contexts and approaches could also invite students to NOS discussions on a deeper level. However, if a more complex NOS discussion is to become a reality, then teachers must develop an ability to seize the possibilities that these different contexts open up. It has been argued that the ability to seize the moment (i.e., teaching NOS on the spur of the moment) is imperative if more nuanced images of science are to become a reality in science education (Hansson and Leden 2016; Herman et al. 2013). That the teachers challenged themselves during the focus group discussions can be seen in the tensions between different rationales. The teachers single out some aspects as particularly abstract and difficult to teach in the early years (arguing from the point of maturity and experience), but still argue that some of these aspects are important to introduce at an early stage (arguing from the point of practice makes perfect). In other cases, the different rationales support each other, for instance when teachers look for approaches or contexts (arguing from the point of teaching approaches or choice of context) that will provide possibilities to start discussing some issues early and then come back to these issues at increasing levels of depth (taught in different contexts with different approaches) at later stages.

As discussed above, the teachers argue that an inclusion of NOS is made possible through appropriate contexts and/or teaching approaches. Thus, if NOS is to become an important part of science teaching - at any stage - there is a need for instructional material. Much work has already been done in this area (e.g., Allchin 2012; Clough 2011; Henke and Höttecke 2015); however, these kinds of materials are not familiar to most teachers. Accordingly, teacher education needs to support teachers with examples of contexts and cases suitable for NOS teaching.

This article has followed a line of research in which teachers' voices are listened to and taken seriously. The results add to the understanding as to why inclusion of specific NOS issues, according to teachers, become possible or not in the science teaching at a certain educational stage. As teachers are important keys to what takes place in the classroom, their perspectives on both NOS teaching in general, and NOS progressions in particular, have to be taken into consideration. Teachers' suggestions and rationales provide important information for teacher education regarding productive ways to challenge both pre- and in-service teachers in their taken-for-granted practices. Some implications from the results in this article seem of particular importance. Firstly, after taking part in this research project, it was still difficult for the teachers to make clear suggestions for NOS progression when it came to adding complexity (i.e., deeper treatment of issues) over the years. One way to deal with this in teacher education could be to encourage teachers to explore different perspectives on NOS, both in relation to teaching and policy documents, and as a way to deepen their own understanding. This could provide possibilities for teachers to develop confidence to deal with conflicting perspectives and tensions related to NOS in their teaching. Secondly, in relation to previous research, one of the more controversial results in this study is that the teachers suggest an early start for some of the more complex topics. Thus, introducing abstract NOS issues in teacher education by providing pre-service teachers with the experience of planning, implementing, and reflecting on teaching, could challenge traditional ways of looking at the teaching of such 
issues. Teachers' own experiences of success, as well as stories from other teachers' experiences, could significantly influence the development of practice. However, more studies focusing teachers' perspectives on NOS teaching are needed in order to create possibilities to bridge the gap between research and science classroom practice.

Open Access This article is distributed under the terms of the Creative Commons Attribution 4.0 International License (http://creativecommons.org/licenses/by/4.0/), which permits unrestricted use, distribution, and reproduction in any medium, provided you give appropriate credit to the original author(s) and the source, provide a link to the Creative Commons license, and indicate if changes were made.

\section{References}

American Association for the Advancement of Science (AAAS). (2009). Benchmarks for science literacy. New York: Oxford University Press.

Abd-El-Khalick, F. (2012). Nature of science in science education: toward a coherent framework for synergistic research and development. In B. J. Fraser, K. Tobin, \& C. McRobbie (Eds.), Second international handbook of science education (Vol. 2, pp. 1041-1060). Dordrecht: Springer.

Akerson, V. L., Buck, G. A., Donnelly, L. A., Nargund-Joshi, V., \& Weiland, I. S. (2011). The importance of teaching and learning nature of science in the early childhood years. Journal of Science Education and Technology, 20(5), 537-549.

Akerson, V., \& Donnelly, L. A. (2010). Teaching nature of science to K-2 students: what understandings can they attain? International Journal of Science Education, 32(1), 97-124.

Allchin, D. (2011). Evaluating knowledge of the nature of (whole) science. Science Education, 95(3), 518-542.

Allchin, D. (2012). The Minnesota case study collection: new historical inquiry case studies for nature of science education. Science \& Education, 21(9), 1263-1281.

Bell, R. L. (2006). Perusing Pandora's box: exploring the what, when, and how of nature of science instruction. In L. B. Flick \& N. G. Lederman (Eds.), Scientific inquiry and nature of science (pp. 427-446). Dordrecht: Springer.

Carey, S., \& Smith, C. (1993). On understanding the nature of scientific knowledge. Educational Psychologist, 28(3), 235-251.

Clough, M. P. (2006). Learners' responses to the demands of conceptual change: considerations for effective nature of science instruction. Science \& Education, 15(5), 463-494.

Clough, M. P. (2011). The story behind the science: bringing science and scientists to life in post-secondary science education. Science \& Education, 20(7-8), 701-717.

Cobern, W. W., \& Loving, C. C. (1998). The card exchange: introducing the philosophy of science. In W. F. McComas (Ed.), The nature of science in science education: rationales and strategies (pp. 73-82). Dordrecht: Kluwer Academic.

Deniz, H., \& Adibelli, E. (2015). Exploring how second grade elementary teachers translate their nature of science views into classroom practice after a graduate level nature of science course. Research in Science Education, 45(6), 867-888.

Duschl, R. A., \& Wright, E. (1989). A case-study of high-school teachers decision-making models for planning and teaching science. Journal of Research in Science Teaching, 26(6), 467-501.

Duschl, R., Erduran, S., Grandy, R., \& Rudolph, J. (2006). Guest editorial: science studies and science education call for papers deadline: March 31, 2007. Science Education, 90(6), 961-964.

Duschl, R., Maeng, S., \& Sezen, A. (2011). Learning progressions and teaching sequences: a review and analysis. Studies in Science Education, 47(2), 123-182.

Driver, R., Leach, J., Millar, R., \& Scott, P. (1996). Young people's images of science. Bristol: Open University Press.

Eflin, J. T., Glennan, S., \& Reisch, G. (1999). The nature of science: a perspective from the philosophy of science. Journal of Research in Science Teaching, 36(1), 107-116.

Erduran, S., \& Dagher, Z. R. (2014). Reconceptualizing the nature of science for science education: Scientific knowledge, practices and other family categories. Dordrecht: Springer.

Glaser, B. G., \& Strauss, A. L. (1967). The discovery of grounded theory: Strategies for qualitative research. New York: Aldine de Gruyter.

Halkier, B. (2010). Fokusgrupper [Focus groups]. Malmö: Liber.

Hansson, L., \& Leden, L. (2016). Working with the nature of science in physics class: turning 'ordinary' classroom situations into nature of science learning situations. Physics Education, 51(5), 55001-55006.

Henke, A., \& Höttecke, D. (2015). Physics teachers' challenges in using history and philosophy of science in teaching. Science \& Education, 24(4), 349-385. 
Herman, B. C., Clough, M. P., \& Olson, J. K. (2013). Teachers' nature of science implementation practices 2-5 years after having completed an intensive science education program. Science Education, 97(2), 271-309.

Hodson, D. (2009). Teaching and learning about science: language, theories, methods, history, traditions and values. Rotterdam: Sense Publishers.

Hodson, D. (2014). Nature of science in the science curriculum: Origin, development, implications and shifting emphases. In M. R. Matthews (Ed.), International handbook of research in history, philosophy, and science teaching (pp. 911-970). Dordrecht: Springer.

Irzik, G., \& Nola, R. (2011). A family resemblance approach to the nature of science for science education. Science \& Education, 20(7), 591-607.

Jenkins, E. W. (2013). The 'nature of science' in the school curriculum: the great survivor. Journal of Curriculum Studies, 45(2), 132-151.

Johansson, A.-M., \& Wickman, P.-O. (2011). A pragmatist understanding of learning progressions. In B. Hudson \& M. A. Meyer (Eds.), Beyond fragmentation: didactics, learning and teaching in Europe (pp. 47-59). Leverkusen: Barbara Budrich Publishers.

Johansson, A.-M., \& Wickman, P.-O. (2012). What should students learn about scientific inquiry? A comparative study of 50 years of the Swedish national curricula. Nordic Studies in Science Education, 8(3), 197-212.

Lederman, N. G. (1992). Students' and teachers' conceptions of the nature of science: a review of the research. Journal of Research in Science Teaching, 29(4), 331-359.

Lederman, N. G. (2007). Nature of science: past, present, and future. In S. K. Abell \& N. G. Lederman (Eds.), Handbook of research on science education (pp. 831-879). Mahwah: Lawrence Erlbaum Associates, Publishers.

Lederman, N. G., Abd-El-Khalick, F., Bell, R. L., \& Schwartz, R. S. (2002). Views of nature of science questionnaire: toward valid and meaningful assessment of learners' conceptions of nature of science. Journal of Research in Science Teaching, 39(6), 497-521.

Leden, L., Hansson, L., Redfors, A., \& Ideland, M. (2015). Teachers' Ways of Talking About Nature of Science and Its Teaching. Science \& Education, 24(9-10), 1141-1172.

Matthews, M. R. (2012). Changing the focus: From nature of science (NOS) to features of science (FOS). In M. S. Khine (Ed.), Advances in nature of science research: concepts and methodologies (pp. 3-26). Dordrecht: Springer.

McComas, W. F. (1998). The principal elements of the nature of science: Dispelling the myths. In W. F. McComas (Ed.), The nature of science in science education: rationales and strategies (pp. 53-70). Dordrecht: Kluwer Academic.

McComas, W. F., Clough, M. P., Almazroa, H. (1998). The role and character of the nature of science in science education. In W. F. McComas (Ed.), The Nature of Science in Science Education: Rationales and Strategies (pp 3-39). Dordrecht: Kluwer Academic.

Morgan, D. L. (1997). Focus groups as qualitative research. Thousand Oaks: Sage.

National Research Council (NRC). (2012). A framework for K-12 science education: Practices, crosscutting concepts and core ideas. Washington, D.C.: National Academy Press.

NGSS Lead States (2013) Next generation science standards: for states, by states. Washington, DC: National Academies Press.

Nott, M., \& Wellington, J. (1998). Eliciting, interpreting and developing teachers' understandings of the nature of science. Science \& Education, 7(6), 579-594.

Osborne, J., Collins, S., Ratcliffe, M., Millar, R., \& Duschl, R. (2003). What "ideas-about-science" should be taught in school science? A Delphi study of the expert community. Journal of Research in Science Teaching, 40(7), 692-720.

Perry, W. G. (1999). Forms of intellectual and ethical development in the college years: a scheme. San Francisco: Jossey-Bass Publishers.

Robson, C. (2011). Real world research: A resource for users of social research methods in applied settings. Chichester: Wiley.

Sjøberg, S. (2010). Naturvetenskap som allmänbildning: en kritisk ämnesdidaktik [Science as literacy]. Lund: Studentlitteratur.

Skolverket (2011a). Curriculum for the compulsory school system, the pre-school class and the leisure-time centre 2011. Stockholm: Swedish National Agency for Education.

Skolverket (2011b). Kommentarmaterial till kursplanen i fysik [commentary to the physics curriculum]. Stockholm: Swedish National Agency for Education.

Smith, C. L., Maclin, D., Houghton, C., \& Hennessey, M. G. (2000). Sixth-grade students' epistemologies of science: The impact of school science experiences on epistemological development. Cognition and Instruction, 18(3), 349-422.

Smith, C. L., \& Wiser, M. (2015). On the importance of epistemology-disciplinary core concept interactions in LPs. Science Education, 99(3), 417-423.

van Dijk, E. M. (2011). Portraying real science in science communication. Science Education, 95(6), 1086-1100. 
Wibeck, V. (2010). Fokusgrupper: om fokuserade gruppintervjuer som undersökningsmetod [Focus groups: on focused group interviews as a research method]. Lund: Studentlitteratur.

Wickman, P.-O., \& Ligozat, F. (2011). Scientific literacy as action: Consequences for content progression. In C. Linder, L. Östman, D. A. Roberts, P.-O. Wickman, G. Erickson, \& A. MacKinnon (Eds.), Exploring the landscape of scientific literacy (pp. 145-159). New York: Routledge. 